\title{
Influence of foreign alliances on the performance of small-scale agricultural businesses in South Africa: A new institutional economics perspective
}

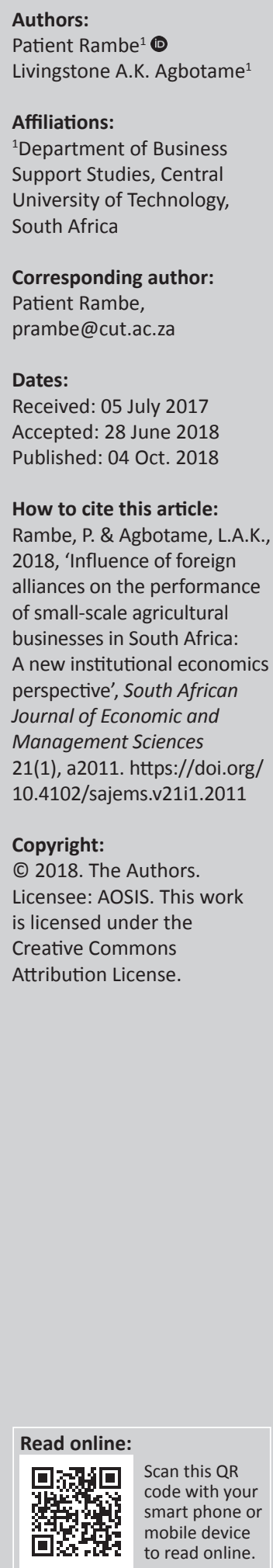

Background: Globalisation has accentuated the need for small-scale agricultural businesses (SSABs) to network horizontally and vertically into world markets. However, the capacity of SSABs to cement foreign alliances to capitalise on business opportunities that the expansion of global markets presents, while simultaneously mitigating against the negative forces of globalisation remains a grey area.

Aim: The study sought to contribute to internationalisation literature by examining: (1) the extent to which SSABs' owner and/or managers in selected South African provinces establish foreign alliances, (2) whether there are any statistically significant differences in SSABs' performance based on their extent of establishment of foreign alliances.

Setting: The setting for this study was Vryburg-Pokwani in the North West and Northern Cape provinces of South Africa, respectively.

Method: A survey was conducted on 151 SSAB owner and/or managers in the aforementioned study area.

Results: The results revealed that although a majority $(51.7 \%)$ had some (i.e. few) foreign alliances, $48.3 \%$ of SSABs had no foreign alliances at all. The results also demonstrated that the establishment of foreign alliances was positively and statistically significantly related to the performance of SSABs in the Vryburg-Pokwani area. Post-hoc comparisons (Bonferroni) results showed that while SSABs with 1-2 foreign alliances perform better than those with no foreign alliances at all, those SSABs with 6-10 foreign alliances perform better than those with none, 1-2 and 3-5 foreign linkages respectively.

Conclusion: Since SSABs with foreign alliances tended to outperform those that were dependent on domestic links, the extent to which the economic benefits derived from internationalisation are reinvested into the businesses for the continued sustenance of businesses needs more rigorous investigation.

\section{Introduction and problem statement}

While the forces of globalisation such as trade liberalisation and structural adjustment programmes have led to the increased integration of world markets (Reardon \& Barrett 2000; Weilbach 2015), the irony is that only a few small-scale agricultural businesses (SSABs) in developing countries, such as South Africa, have the ability and capacity to be integrated into these lucrative markets to derive substantial dividends (Agbotame 2015; Louw, Nhemachena \& Van Zyl 2008). South Africa's Small National Business Act (2003) defines SSABs as those agricultural firms employing less than 100 employees, with a total annual turnover of less than R5 million and a total gross asset value of less than R5 million (National Small Business Amendment Act 2003). These should be differentiated from large agribusinesses, which are large companies (in terms of workforce, annual turnover, and asset value) that are involved in the production, processing, and marketing of value-added products and services. SSABs can also be distinguished from small agribusinesses, which are market and private business-oriented entities involved in the production, storage, distribution, and processing of agro-based products, the supply of production inputs, and the provision of extension and research services (Gandhi 2014). Louw (2007) defines agribusinesses as industries, ranging from suppliers of inputs and services to producers, to processors and marketers of agricultural products, manufacturers, exporters, retailers, the distribution systems, and consumers. Therefore, although these enterprises deal with inputs, processes, and outputs that could be related to agriculture, their scope of production, marketing, and service provision extend beyond agriculture to include non-agricultural products such as retail and fisheries. 
The complexity of integrating SSABs (i.e. small-, micro-, and medium-sized agricultural firms involved in the production, processing, and marketing of value-added products and services) into the world markets can be attributed to several challenges. These constraints include lack of physical access to global markets due to information asymmetries (Ha, Bosch \& Nguyen 2015), lack of technical and managerial skills relevant to engage with global players (Frimpong 2015; Louw et al. 2008), and the low competitiveness of agricultural products from emerging economies (Jabbar \& Akter 2008). Furthermore, the high production costs, including the poor quality of products and services from these economies (Dung \& Jenicek 2008; Ha et al. 2015), further complicate their international competitiveness. Although these challenges are not peculiar to SSABs but may resonate with the international competitiveness barriers of established businesses in developing countries, small SSABs in developing countries such as South Africa tend to bear the brunt of smallness the most due to limited economies of scale and resource constraints. As such, the potential and possibilities of trade liberalisation have remained a mirage for most SSABs that fail to tap into the lucrative world markets.

In view of the rapid transformation of food and agricultural markets, increased international competition due to trade liberalisation, and the rise of global agricultural firms, the need for higher levels of managed coordination, vertical integration and foreign alliances (Kirsten \& Sartorius 2002; Louw et al. 2008) cannot be over-emphasised. For South African SSABs, the need for stronger foreign alliances stems from their weak links to global markets and financial systems (Wroblewski \& Wolff 2010), the need for rapid flexibility to sell high-quality products at competitive prices on the world markets (Centre for Rural Legal Studies 2003), and the importance of agricultural businesses' accessing world markets faster, further, and deeper at comparatively lower cost (Weilbach 2015). While the establishment of foreign alliances is critical to the integration of SSABs into the world economy (PWC Agribusinesses Insights Survey 2014/2015), the scarcity of capital, the lack of infrastructure development in the rural areas, coupled with the high cost of farming inputs and utilities (Frimpong 2015), often hinder SSABs' ability to collaborate and engage with international partners to reduce the cost of exports and improve the efficiency of engaging in international business.

While the formation of international alliances is critical to improving SSABs' international competitiveness (Agbotame 2015), what remains unclear is the extent to which such businesses engage in foreign alliances and the implications of such behaviour for their performance. To bridge this research gap, the current study sought to address the following pertinent questions:

- To what extent do SSABs in Vryburg-Pokwani areas establish foreign alliances?

- Are there significant differences in SSABs' performance based on their extent of establishment of foreign alliances? If so, what is the nature of such differences?
Although SSABs' performance is often measured in terms of the profitability, growth, and survival of these businesses (Madhoushi et al. 2011; Wiklund \& Shepherd 2005), the most common measures of firm performance include the number of employees employed in the business, growth in pre-tax profit, gross turnover, and increase in exports as a percentage of annual turnover.

The rest of the article is structured as follows: a problem background is rendered, the theoretical perspective and the literature review are provided, the research methodology is articulated, findings are presented and discussed, the implications and directions for future research are rendered, and then a conclusion is provided.

\section{Problem background}

The importance of SSABs' establishment of foreign alliances should be understood against the background of increased trade liberalisation, increasing international competition in global trade, and the predominantly export-oriented nature of the agricultural sector in emerging economies. While the sectors of the South African economy range from manufacturing, mining, agriculture, communications, tourism, wholesale and retail trade, finance, business services and investment incentives (Media Club South Africa 2018), this study is preoccupied with SSABs, some of which belong to the agro-processing industry. The agro-processing industry is a sub-sector of manufacturing that deals with the conversion of products from field crops, horticulture, fisheries, and forestry from raw materials and inputs into semi-processed, processed, and value-added goods and products (FAO 1997).

\section{Trade liberalisation and agricultural constraints}

Agbotame (2015) observes that when international sanctions were imposed on South Africa from 1979 to 1994, the apartheid government heavily subsidised and protected SSABs from foreign competition to improve their self-sufficiency and absorb excessive external pressure. With the attainment of democracy in 1994, the resultant integration of the South African agricultural economy into the world economy and the ANC government's adoption of trade liberalisation exposed the formerly protected SSABs to global competition and the vagaries of international trade. The Centre for Rural Legal Studies (2003) highlights that the government's adoption of trade liberalisation implied limited state intervention in economic management, which allowed the agricultural market to operate strictly on the basis of the law of supply and demand, and enabled competition throughout the economy.

While it can be argued that 22 years into liberal democracy, SSABs have sufficiently acclimatised to the demands of global competition (e.g. improved resource efficiency, solid international networks, and high-quality products), multiple impediments continue to undermine their effective participation in the global economy. Trade liberalisation has not substantially benefited South African SSABs due to: 
their predominantly rural location, poor road networks which increase the logistical costs of product and service provision, inadequate farming infrastructure (e.g. efficient irrigation and storage facilities), low agricultural incomes, volatile weather patterns, widespread poverty, and a lack of food processing industries (Botha 2015). Collectively, these agricultural barriers increase the cost of doing business, complicate optimal pricing, and undermine the efficient sale of agricultural commodities.

\section{Increasing international competition}

As Doyer et al. (2007) aptly observe, the process of deregulation and liberalisation which started in the 1980s exposed South African SSABs to international trends and competition, compelling them to shoulder responsibilities and risks in agricultural markets that government agencies previously assumed. They elaborate, that confronted with the need to improve their ability to compete in current and new markets with new competitors while focusing on expanding their domestic market presence and power, based on valueadded products, South African agribusinesses including SSABs were compelled to assess innovative options in their governance structures. This unfolded in an environment characterised by increasing domestic and international competition, a new political and social environment based on equity principles, and increasingly complex consumer demands. It can be inferred from Doyer et al. (2007) that the formation of strategic alliances with foreign partners and subsidiaries could contribute to improved sensitivity of SSABs to foreign consumer demands, flexible responsiveness to foreign market needs, and improvement of SSABs' international competitiveness.

\section{Export orientation of the agricultural sector}

This study's preoccupation with SSABs' foreign alliances is hinged on the understanding that the agricultural sector in South Africa is export oriented, which makes the sector vulnerable to the vagaries of international trade. For instance, the Centre for Rural Legal Studies (2003) acknowledges that notwithstanding the agricultural sector's limited contribution to South Africa's annual national income (or gross domestic product, GDP), the sector accounted for a relatively high share of the total goods exported from South Africa. While agriculture contributes less to GDP (less than 3\% for primary agricultural products), agriculture accounts for a relatively high share of South African exports: about $8 \%$ of total exports (Agbotame 2015; Department of Agriculture, Forestry \& Fisheries 2012). This large volume of agricultural exports compels SSABs to establish foreign alliances to expedite their sales, improve the competitiveness of such exports, and reduce the transaction costs of conducting business in foreign lands. The formation of strategic alliances cannot be ignored in the performative dimensions of small agribusinesses. PWC Agribusinesses Insights Survey (2014/2015) reports that better penetration of new markets is regarded as one of the main determinants of the growth expectations of such businesses. The survey results affirm that accessing new markets allows agribusinesses to broaden their reach and increase their potential to sell products and services to more customers.

\section{Theoretical framework}

The Transaction Cost Approach (TCA) is the central anchor of the New Institutional Economics (NIE) theory. Transaction costs encapsulate the costs that arise from the relations between individuals (or businesses) whenever agents want to make a deal, which may or may not take the form of a market exchange (Matthews 1986; Platteau 2008). Besides the individual characteristics of partnering firms, alliances are also subject to transaction costs arising from the misalignment of partners' goals (Eisenhardt 1989) and the project-specific behaviour of partners (Shah \& Swaminathan 2008). It can be assumed that SSABs' ability to actively compete with their rivals on the global market is a function of their capacity to reduce the transactional costs (e.g. insufficient knowledge of the tax regimes and incentives of the foreign alliance partners' countries, trade information asymmetries arising from transacting in new or unfamiliar regional contexts) of doing international business through their collaborations and engagements with foreign partners who are more familiar with the host market conditions than SSAB owners or managers.

Literature presents two conditions under which transaction costs may arise from: (1) informational incompleteness and asymmetries, which happens when the parties miss information needed to determine whether the terms of an agreement are mutually acceptable and whether these terms are actually being met, or (2) the costs resulting from imperfect commitment (Milgrom \& Roberts 1992; Platteau 2008). Imperfect commitment implies the inability of parties to bind themselves to follow through on threats and promises that they would like to make but which, having made, they would later like to renounce (Platteau 2008). If mutual benefit arises from a SSAB and foreign partner's exchange of strategic marketing information on agricultural products in foreign niche markets less familiar to the SSAB, the SSABs' negation of such information that makes the alliance beneficial to the SSAB would constitute a transaction cost to the SSAB. By the same token, the SSAB and foreign alliance partner's inability to take advantage of the opportunities created within the global market (e.g. declining petrol prices, foreign currency fluctuations' impact on export volumes), including failure to mitigate the threats associated with the vagaries of international trade, would be extra transaction costs for both entities (the SSAB and foreign alliance partner).

From the transaction cost perspective, the aim of institutions is to reduce transaction costs so as to allow agents to seize economic opportunities; therefore, an efficient institution is simply an arrangement that minimises such costs or one that maximises the joint wealth of all the parties concerned (Allen \& Lueck 2002; Platteau 2008). The ability of institutions to maximise the economic benefits, minimise the costs, and hence magnify the net worth of the foreign alliance rests on 
the quality of the resources these parties (SSAB and alliance partner) possess, degree of risk involved in entering foreign markets, these alliance partners' technological capabilities, and dynamic capabilities including the superiority of their knowledge of foreign markets. For the SSABs, which normally have a strong survivalist orientation and are profoundly resource squeezed, the need for institutions that minimise the transaction costs and increase the net worth of the foreign alliance partners cannot be ignored as SSABs have limited chances of making an international impression on the global market.

\section{Literature review \\ Characterisation of foreign alliances}

The foreign alliances are a part of the broader business networking that leads to internationalisation of firms. Such strategic alliances are voluntary collaborations between organisations that involve the exchange, sharing or co-development of products, technologies, and services to pursue common goals or meet critical business needs (Gulati 1998; Kishna et al. 2015; Lin 2012). Such international networking can take different formats such as the establishment of international subsidiaries, international collaboration with foreign firms through strategic alliances, international partnerships, contractual agreements, and production investments in foreign companies (Mellen 2009; Ndjike 2016). Therefore, foreign alliances can take different forms: the formation of inter-firm alliances, bilateral relationships, production-related agreements, and foreign subsidiaries. All these institutional arrangements are integral components of the internationalisation of firms, which entails the firm's involvement in international business through exportation, the presence of foreign subsidiaries, share ownership by foreigners, and the appointment of foreigners in the organisational structure of local firms (Chelliah et al. 2010). Since small agricultural businesses do not meet all attributes of large firms' foreign alliances, such as having foreign subsidiaries, share ownership by foreigners, and appointment of foreigners in the business management structure of the local firm due to severe resource constraints, the current study's conception of foreign alliances exclusively covers the establishment of strategic alliances and partnerships with foreign firms.

\section{The value of agro-processing alliances}

From an internal perspective, agri-food systems' linkages with the rest of the economy are important preconditions for integrating rural firms into urban economies and are the longterm solutions for agricultural growth, poverty reduction, and economic growth (Louw et al. 2010; Memedovic \& Shephard 2009). The connectivity between local and urban agro-processing firms is just as important as the linkages between rural firms and their international partners and subsidiaries. For instance, small agricultural producers' collective organisation (i.e. among themselves) in liaison with foreign partners improves their assimilation of global production and marketing practices into their systems and creates new local institutions that support local knowledge building (Perez-Aleman 2012). More so, the capacity of small agricultural producers to increase connections among themselves and with specialised organisations nationally and globally contributes to these producers' effective acquisition and application of new knowledge and their improved capacity to innovate locally (Perez-Aleman 2012). Foreign alliances are conceived to facilitate the development of sustainable innovations, which depend on capabilities and resources that are spread over organisations from different industries (Van Tulder et al. 2015). There is growing consensus that foreign networks with varied expertise facilitate learning by creating horizontal relations between producers, as well as links to external organisations that can act as knowledge bridges between different communities and knowledge resources (Gomes 2006; McDermott, Corredoira \& Kruse 2009; Perez-Aleman 2012).

From an international perspective, Kawa and Kaitira (2007) considered the strengthening of links between local and foreign firms in Tanzania as critical to the strategic marketing of agricultural products and the promotion of optimal agribusiness returns based on a competitive, efficient, and equitable marketing system. Yet South African SSABs tend to operate in predominantly rural communities where internet penetration, which increases virtual connectivity and the forging of alliances with distant communities, is conspicuously absent. Therefore, the affordances of foreign alliances, such as the acquisition and exchange of complementary resources including entry into new markets and technologies (Kishna et al. 2015; Rothaermel \& Boeker 2008) may be difficult to contemplate for such rural-bound SSABs.

\section{Studies on agribusinesses' foreign alliances}

Studies on the alliances of agribusinesses tend to focus more on the forward and backward linkages between the agribusinesses and various stakeholders within a domestic economy (Industrial Development Corporation [IDC] 2015; Mucavele 2009; Olomola 2013) and ignore the foreign alliances of these firms. In recognition of intra- and intersector alliances, Olomola (2013) highlights how discrimination against small-scale farmers in Nigeria is evident in the lack of effective links with larger agribusinesses for the enhancement of productivity and improvement of access to markets. While the intra- and inter-sector linkages perspective is useful for demonstrating the contribution of such domestic linkages to productivity enhancement within the value chain, such a perspective is insufficient for illuminating full comprehension of the dynamics of international trade, drawing on foreign networks. When an international perspective of alliances is considered, the focus of analysis turns to: conformity to global standards, which affects food safety and exploitation of local knowledge (Perez-Aleman 2012); agribusiness investors' weak links to global financial systems and the associated liquidity risks (Wroblewski \& Wolff 2010), and the trade arrangements established in the South African agricultural industry since the demise of the marketing boards (Doyer et al. 2007). Doyer et al. (2007) observe that in relation-based alliances (for example, joint ventures and 
partial ownership arrangements) agro-processing parties are ex ante interested in mutual benefit that might arise from the transaction and the ex post monitoring of the relationship to ensure that it continues and delivers the envisaged mutual benefits.

Other studies have focused on institutional arrangements that give effect to more competitive trade and the associated barriers to internationalisation (Kawa \& Kaitira 2007; Lloyd-Reason, Deprey \& Ibeh 2009). Although not related to agriculture, Kishna et al.'s (2015) study analysed the role of strategic alliances in creating legitimacy for an emerging sustainable technology. The study reported that firms increase their market and social legitimacy by accessing the sustainable technology of an alliance partner, by collaboratively developing a sustainable technology or increasing customers' access to the technology of a partner and increasing production capacity.

However, the establishment of foreign alliances and partnerships cannot be assumed to be without its own challenges and constraints. For instance, although foreign alliances in small-scale agricultural businesses are credited with increasing access to agricultural markets and services, scaling up small holder production through increasing the quantity, quality, and diversity of goods they produce for foreign markets, these partnerships have several challenges (The Governing Council 2013). For instance, these alliances require SSABs to abandon their hierarchical agricultural production approaches and blueprints, while demanding extensive consultation as no single agricultural partner (be they farmers, private investors, researchers, governments or donors) has comprehensive solutions to challenges confronting agriculture (The Governing Council 2013). More so, the thriving of foreign partnerships also depends on farmers' training (which requires time, energy and financial investments), proper organised action based on effective partnership facilitation, and farmers' extensive access to research and technology (Berdegué, Biénabe \& Peppelenbos 2008), conditions which are not normally obtained in rural areas where most SSABs operate. More so, the alignment of SSABs partners' disparate interests and visions and the need to reach consensus, though critical to creating lasting commitments founded on value for money (FAO 2016), are an inextricably complex matter. Moreover, the definition of roles for partners in line with the unique capabilities, skills, and expertise they bring to the agricultural partnership, should be postulated in line with the provision of appropriate incentives designed to reward these roles (FAO 2016). These require strategic thinking, ingenuity in terms of organisational skills, and durable commitment among partners, which cannot be assumed to be consistently prevalent among them.

\section{Firm performance}

Firm performance describes a contested, multi-dimensional construct, which embodies financial, non-financial and growth-related indicators such as sales growth, financial outcomes, and firm growth (Agbobli 2013). Financial measures include sales growth, return on investment; growth in pre-tax profit, gross turnover before tax and non-financial indicators, as well as growth in the number of employees and increase in exports as a percentage of annual turnover. Therefore, firm performance is a multifaceted construct that covers financial and non-financial aspects such as business competitiveness, operational measures on customer satisfaction, and competitive advantage (Bititci 1995; Folan, Browne \& Jagdev 2007; Kaplan \& Norton 1992). That said, this slippery construct varies dynamically in its meaning, depending on its context of use, size of the businesses and sector in which it is applied. For the purpose of this study, performance focused on growth in pre-tax profit over the previous five years, growth in employment over the previous five years and growth in agricultural exports and imports.

\section{Relationship between agro-processing alliances and firm performance}

In their study on enhancing Tanzanian smallholder farmers' market competitiveness, Kawa and Kaitira (2007) report that strengthening links between local and foreign firms increases these firms' capacity to mobilise resources for investment in the agricultural marketing infrastructure in rural areas and improves the international competitiveness of agro-processing and value-addition chains. The ability of agro-processing businesses to engage in strategic alliances with other enterprises is considered to strengthen international collaboration and improve sustainable development capacities, which increase the effective realisation of long-term business goals (Louw \& Emongor 2004; Louw et al. 2010). A 2009 Organisation for Economic Cooperation and Development (OECD) Working Paper on small-, medium- and micro-enterprises (SMMEs) and entrepreneurship highlights top barriers and drivers to SMME internationalisation. The study revealed that Czech, French and Spanish agencies' support for SMMEs' export alliances and networks reflect the observed importance of networks, supply chain links and social ties in stimulating SMME internationalisation and export competitiveness (OECD 2009). In the same vein, the IDC (2015) reports that value chain development in the agricultural and industrial sectors is critical to leveraging the impact of economic linkages on business competitiveness.

However, the internationalisation process, especially the establishment of foreign alliances, has its own fair share of challenges. The extension of agro-processing business operations internationally to develop a regional or global footprint may not detract concentration risk. IDC (2015) observes that concentration risk generally results from an uneven distribution of an institution's exposure to industry and regional sectors, which can generate losses large enough to jeopardise its solvency or profitability. In particular, concentrations of credit exposures in sectors or regions can pose risks to the earnings and capital of any institution in the form of unexpected losses. Although IDC's operations 
resonate more with sector concentration risk than regional concentration risk, a typical firm's operations can trigger regional concentration risk due to the variability of trade advantages and the competitiveness of business operations depending on regional trading conditions.

\section{Research approach}

The study adopted an exploratory, descriptive and quantitative approach. An explorative study is appropriate when the researcher lacks basic information on an area of interest (Fouché \& De Vos 2011). In view of the limited information on the extent to which small, predominantly rural-based agro-businesses in South Africa forge foreign alliances, an explorative study was ideal for providing insights into such a phenomenon. Since the current study sought to render an informative picture of the extent to which SSABs forged alliances with other foreign businesses, a descriptive approach assisted in painting a vivid picture of the specific details of the situation at that particular time (Krueger \& Neuman 2006). This empirical approach was relevant to this study because although foreign alliances are sufficiently theorised in mainstream literature, there is limited empirical literature in the South African context on the foreign alliances of rural-based SSABs.

\section{Population, sampling frame and sample}

The co-author of this study approached agricultural departments in these areas, which revealed that there were approximately 3788 small-scale businesses in the VryburgPokwani areas. The lack of accurate records on SSABs can be attributed to the high failure rate of SSABs, which complicate the compilation of current reliable statistics on such businesses.

The sampling frame of the current study consisted of 899 SSABs situated in the Vryburg-Pokwani districts of the North West and Northern Cape provinces. This figure was based on estimates obtained from the various District Departments of Agriculture within the study area. Subsequently, the sample size was computed out of the working population by using a Macorr sample calculator at $95 \%$ confidence level. Subsequently, a total of 269 agro-based businesses were randomly selected. Of this number a total of 151 respondents successfully completed the survey, constituting a response rate of $56.1 \%$.

\section{The research instruments}

Section A of the questionnaire solicited information on the SSAB owner or manager's demographics such as their age, gender, academic qualification, business management skills, agricultural skills, and entrepreneurial skills. The same section also extracted business-related information such as the duration of operation of the business, main business activity, form of ownership, and number of employees the business employs. Section B established the extent of SSABs' engagement in foreign business, type of foreign business activities, and the number of foreign alliances or partnerships or collaborations the business engaged in. Section C examined the relationship between such foreign alliances and firm performance. To establish the extent to which SSABs established foreign alliances, the SSABs were requested to highlight the number of foreign alliances they had. The options were provided on a five-point scale comprising ' 1 ' (no foreign alliance), ' 2 ' (1-2 foreign alliances), ' 3 ' (3-5 foreign alliances), 4 (6-10 foreign alliances), and 5 (more than 10 foreign alliances).

\section{Data analysis}

The data collected was analysed using the Statistical Package for the Social Sciences (SPSS) version 21. Descriptive analysis, comprising percentage analysis and pie charts, was used for the descriptive summary of results. Inferential statistics, especially analysis of variance (ANOVA) was used to quantitatively ascertain the degree of relevance of the internationalisation indicator (e.g. foreign alliances) on the performance of small-scale agro-based businesses. Correlation analysis was employed to examine the relationships between foreign alliances and business performance.

\section{Validation of the research instrument}

The validation of the self-constructed structured questionnaire involved the determination of its construct validity and reliability. Construct validity takes into account the measuring instrument applied, compared with existing theoretical measures (Cooper \& Schindler 2011; Zikmund et al. 2013). The measurement instrument applied in this study was developed from the existing literature on businesses' engagement in foreign alliances, thereby ensuring construct validity.

According to Leedy and Ormrod (2010), reliability is the consistency with which a measuring instrument yields a certain result when the entity being measured has not changed. A Cronbach's alpha coefficient was used to establish the reliability of the instrument and a value of 0.70 is normally considered to be an appropriate level of acceptable reliability. All four indexes ('importance and/or relevance of globalisation', 'impact of globalisation', 'longterm performance expectations', and 'long-term performance expectations under globalisation') demonstrated excellent reliability as their respective coefficients were $0.921,0.906$ and 0.885 . A second measure of internal consistency is the extent to which each individual item correlates with its total score on the index. Correlation coefficients were computed as estimates of such item-total correlations. A coefficient of 0.50 indicates a strong correlation. The item-total correlations ranged between 0.57 and 0.78 , and the average-item correlations for each of the three indexes were $0.72,0.69$ and 0.65 , all markedly above 0.50 .

\section{Results and discussion Gender distribution of respondents}

Of the 151 respondents, $20.5 \%$ were female while $79.5 \%$ were male as depicted in Table 1 and Figure 1. 
TABLE 1: Demographic characteristics of owners and/or managers.

\begin{tabular}{|c|c|c|c|c|}
\hline Question & Characteristic & Number & Mean score (out of 30 ) & Standard deviation \\
\hline \multirow[t]{2}{*}{ What is your gender? } & Male & 120 & 17.8 & 6.5 \\
\hline & Female & 31 & 17.6 & 4.5 \\
\hline \multirow[t]{4}{*}{ What is your age group? } & $21-30$ years & 10 & 17.8 & 4.5 \\
\hline & $31-40$ years & 18 & 16.9 & 5.0 \\
\hline & $41-50$ years & 53 & 17.5 & 6.0 \\
\hline & $51-60$ years & 40 & 21.0 & 6.1 \\
\hline \multirow[t]{6}{*}{ What is your highest academic qualification? } & None & 21 & 13.6 & 4.6 \\
\hline & Primary & 22 & 13.1 & 3.9 \\
\hline & NSC and below & 35 & 14.7 & 4.4 \\
\hline & Tertiary qualification & 22 & 19.7 & 5.5 \\
\hline & Diploma or degree & 38 & 22.3 & 4.8 \\
\hline & Postgraduate & 13 & 23.7 & 4.0 \\
\hline \multirow{5}{*}{$\begin{array}{l}\text { At what highest level of education have you } \\
\text { acquired business management skills? }\end{array}$} & High school & 21 & 16.5 & 5.6 \\
\hline & Diploma or degree & 37 & 22.7 & 4.1 \\
\hline & Postgraduate & 7 & 23.1 & 5.0 \\
\hline & Short courses & 27 & 16.5 & 4.8 \\
\hline & None & 45 & 13.0 & 4.7 \\
\hline \multirow{6}{*}{$\begin{array}{l}\text { At what highest level of education have you } \\
\text { acquired agricultural skills? }\end{array}$} & High school & 24 & 16.2 & 4.6 \\
\hline & College & 15 & 22.8 & 4.3 \\
\hline & Diploma or degree & 30 & 22.6 & 4.3 \\
\hline & Postgraduate & 6 & 22.5 & 4.3 \\
\hline & Short courses & 27 & 16.6 & 5.5 \\
\hline & None & 49 & 14.0 & 5.4 \\
\hline \multirow{4}{*}{$\begin{array}{l}\text { At what highest level of education have you } \\
\text { acquired engineering skills? }\end{array}$} & High school & 15 & 17.1 & 5.6 \\
\hline & College & 13 & 21.7 & 6.6 \\
\hline & Diploma or degree & 16 & 23.3 & 3.4 \\
\hline & Postgraduate & 4 & 20.8 & 5.9 \\
\hline \multirow{6}{*}{$\begin{array}{l}\text { At what level of education have you acquired } \\
\text { entrepreneurial skills? }\end{array}$} & High school & 9 & 14.0 & 4.1 \\
\hline & College & 6 & 15.6 & 7.0 \\
\hline & Diploma or degree & 25 & 22.5 & 4.2 \\
\hline & Postgraduate & 10 & 24.3 & 4.5 \\
\hline & Short courses & 42 & 19.4 & 4.8 \\
\hline & None & 59 & 14.2 & 5.3 \\
\hline
\end{tabular}

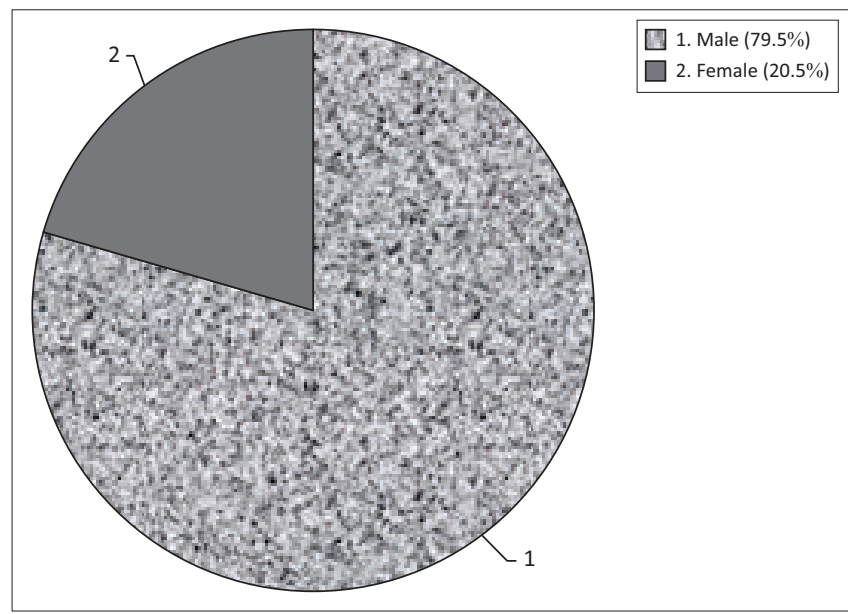

FIGURE 1: Gender analysis of respondents.

The under-representation of women in SSABs could be attributed to the multiple financial, institutional, social, and cultural barriers which continue to impede women's full participation in agro-processing and other agricultural valueaddition services. Prejudices against women, which constrain their access to loan credits (Agbotame 2015; Mpiti 2016), competing family responsibilities (Agbobli 2013; Rambe \& Mokgosi 2016), and power configurations in the family that create skewed access to finance and financial decisionmaking collectively undermine women's participation in small business in general and agribusiness in particular.

\section{Age distribution of participants}

The results of the study revealed that a sizable percentage (35.1\%) of SSAB owners or managers were aged between 41 and 50 years, followed by those between 51 and 60 years who constituted $26.5 \%$ of the sample. The age distribution of participants is illustrated in Figure 2.

The dominance of the 41-60 years age group suggests the significance of prior knowledge and practical experience in related agro-industries prior to the creation and operation of their own agro-businesses. Chiliya and Roberts-Lombard (2012) consider age to have a significant effect on operating a complex business profitably because the accumulation of prior technical and technological experience, business 


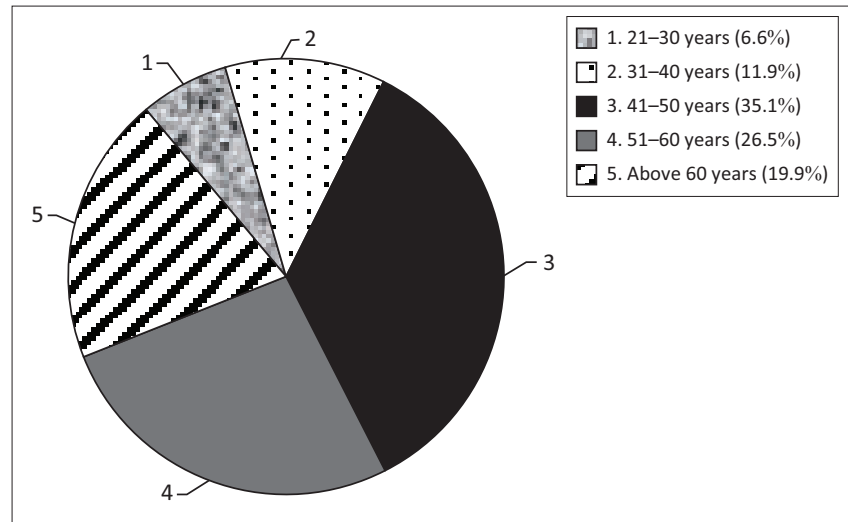

FIGURE 2: Age of respondents.

knowledge and business connections is critical to successful business operations.

\section{Levels of academic qualifications}

The academic qualifications of the owners or managers were considered in order to ascertain their educational profile. The results in Figure 3 show that respondents with tertiary education (tertiary qualifications, diplomas or degrees, postgraduate certificates) constituted $48.4 \%$ of the sample and represented the largest percentage of participants in the study.

Figure 3 reveals that although the majority of SSAB owners or managers were not highly educated, most of them had good tertiary education (tertiary certificate, diploma or degree, or postgraduate qualification). Dzansi, Rambe and Coleman (2015) highlight the significance of entrepreneurial and project knowledge (which are consequences of education and training) in successful venture creation and operation of business.

\section{Level of business-related skills}

The study also examined the business management, basic agricultural, engineering, and entrepreneurial skills base of SSAB owners or managers. Business management skills included marketing skills, financial management skills, and personnel management skills. Basic agricultural skills included soil management, animal husbandry and crop management while basic engineering skills related to fencing, erection of sheds, repairs of equipment and machinery. Entrepreneurial skills comprise risk-taking and the organisation of the resources at owners' or managers' disposal. The results in Figure 4 reveal that $30 \%$ of respondents had no business management skills, 33\% had no agricultural skills, $50 \%$ had no engineering skills while $39 \%$ had no entrepreneurial skills. Despite this, there was also a sizable percentage of SSAB owners or managers with these skills. The results on the level of business-related skills possessed by respondents are summarised in Figure 4.

A sizable percentage (39\%) of these owners and/or managers had business management skills acquired at college, at diploma or degree and postgraduate levels. By the same token, $34 \%$ had agricultural skills acquired at college, diploma or degree and postgraduate levels, while $23 \%$ had engineering

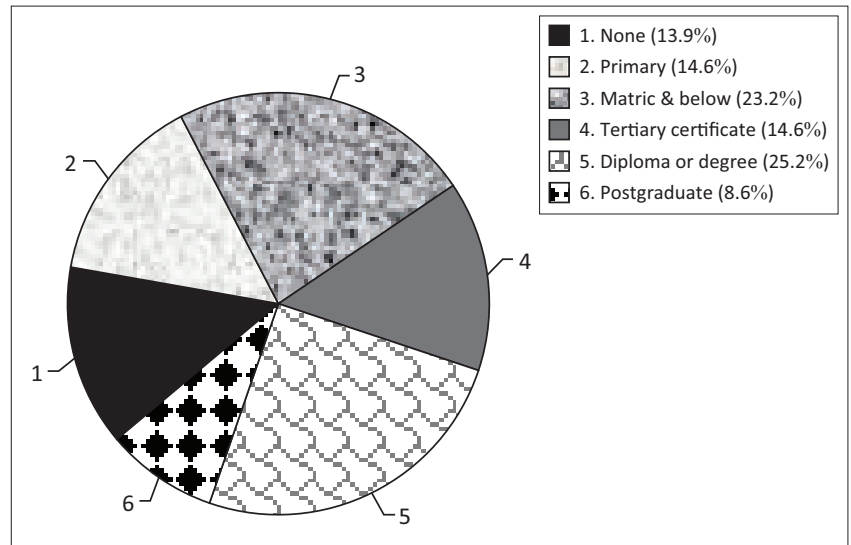

FIGURE 3: Levels of academic qualification.

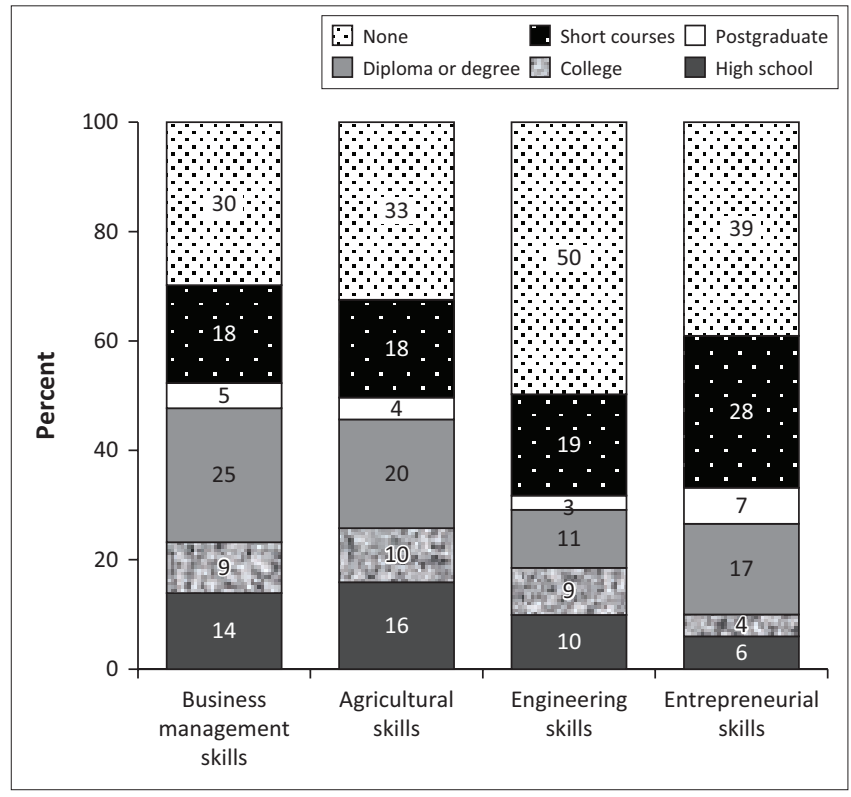

FIGURE 4: Level of education and skills acquired.

skills acquired at college level. A total of $29 \%$ of owners or managers had entrepreneurial skills acquired at the aforementioned levels of college education. It can be argued that SSAB owners or managers were well positioned to run their firms as they had acquired diverse skills critical to successful business performance.

\section{Number of years the business has been in operation}

Since the number of years in business is critical to SSABs' generation of the momentum significant to building foreign alliances, the study sought to establish the duration of operation of the business to determine the level of experience of owners or managers. The results show that $31.8 \%$ of these businesses had been in existence for 11-20 years, and 23.2\% of them had been in operation for over 20 years. About $23.2 \%$ of the businesses had been in operation for 6-10 years. The results on the number of years that SSABs had been operating are summarised in Table 2 and Figure 5.

The analysis presented shows that $78.2 \%$ of the SSABs surveyed have passed the survival stage and this could 
TABLE 2: Business characteristics.

\begin{tabular}{|c|c|c|c|c|c|}
\hline Questions & Characteristics & $\%$ & Number & Mean score (out of 30 ) & Standard deviation \\
\hline \multirow{5}{*}{$\begin{array}{l}\text { How long has the company been } \\
\text { operating? }\end{array}$} & Up to one year & - & 9 & 16.5 & 4.9 \\
\hline & $2-5$ years & - & 24 & 16.0 & 4.7 \\
\hline & $6-10$ years & - & 35 & 18.2 & 5.5 \\
\hline & $11-20$ years & - & 48 & 20.8 & 5.7 \\
\hline & Over 20 years & - & 35 & 14.6 & 6.5 \\
\hline \multirow{4}{*}{$\begin{array}{l}\text { What type of business activity is } \\
\text { the company engaged in? }\end{array}$} & Agri-processing & - & 28 & 21.9 & 5.1 \\
\hline & Livestock farming & - & 61 & 14.4 & 4.5 \\
\hline & Crop farming & - & 43 & 18.9 & 5.7 \\
\hline & $\begin{array}{l}\text { Both livestock and crop } \\
\text { farming }\end{array}$ & - & 18 & 19.1 & 7.6 \\
\hline \multirow{5}{*}{$\begin{array}{l}\text { What form of business } \\
\text { ownership do you practise? }\end{array}$} & Sole proprietor & - & 99 & 16.6 & 6.2 \\
\hline & Partnership & - & 15 & 16.5 & 3.3 \\
\hline & Close Corporation & - & 16 & 21.6 & 4.3 \\
\hline & Private company & - & 17 & 22.8 & 5.1 \\
\hline & Cooperative society & - & 4 & 14.4 & 4.3 \\
\hline \multirow{5}{*}{$\begin{array}{l}\text { Number of employees including } \\
\text { owner or manager: }\end{array}$} & $1-5$ & - & 73 & 14.9 & 5.1 \\
\hline & $6-20$ & - & 28 & 17.0 & 5.7 \\
\hline & $21-30$ & - & 22 & 21.9 & 4.3 \\
\hline & $31-40$ & - & 10 & 24.2 & 5.0 \\
\hline & $41-50$ & - & 18 & 21.9 & 5.4 \\
\hline \multirow{2}{*}{$\begin{array}{l}\text { Is your company engaged in } \\
\text { foreign business? }\end{array}$} & Yes & - & 57 & 23.2 & 4.0 \\
\hline & No & - & 94 & 14.4 & 4.6 \\
\hline \multirow[t]{2}{*}{ Do you engage in importing? } & Yes & - & 12 & 23.5 & 4.2 \\
\hline & No & - & 139 & 17.2 & 6.0 \\
\hline \multirow[t]{2}{*}{ Do you engage in exporting? } & Yes & - & 56 & 23.2 & 4.1 \\
\hline & No & - & 95 & 14.5 & 4.6 \\
\hline \multirow{5}{*}{$\begin{array}{l}\text { Growth in pre-tax profit over } \\
\text { the past five years: }\end{array}$} & Declining & $11-20$ & 6 & 13.9 & 2.9 \\
\hline & Declining - & $1-10$ & 21 & 16.1 & 4.3 \\
\hline & No change & 0 & 26 & 14.4 & 4.8 \\
\hline & Growing & $1-10$ & 65 & 17.1 & 6.0 \\
\hline & Growing & $11-20$ & 33 & 23.4 & 5.0 \\
\hline \multirow{5}{*}{$\begin{array}{l}\text { Growth in size or employment } \\
\text { over the past five years: }\end{array}$} & Declining & $11-20$ & 3 & 15.3 & 2.9 \\
\hline & Declining & $1-20$ & 14 & 17.9 & 5.4 \\
\hline & No change & 0 & 70 & 15.9 & 5.4 \\
\hline & Growing & $1-10$ & 56 & 19.2 & 6.4 \\
\hline & Growing & $11-20$ & 8 & 23.6 & 5.6 \\
\hline
\end{tabular}

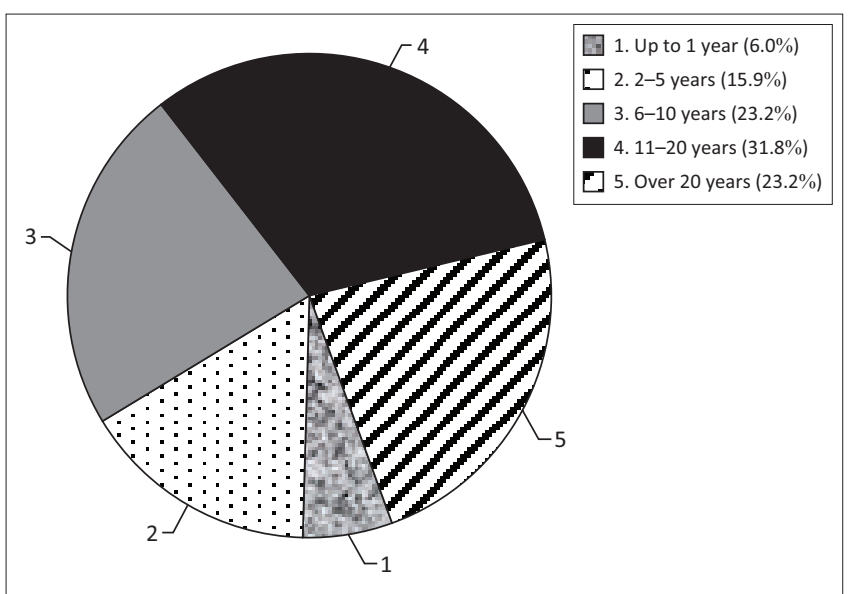

FIGURE 5: Number of years that the business has been in operation.

mean that they stand the chance of growing both locally and internationally. Nieman (2006) considers survival to describe those businesses that have been in operation for more than five years. Taking this description into consideration, it can be argued that the majority of the agricultural businesses have survived as they have transited their first five years of existence.

\section{Type of business activity}

The study also established the type of activities SSABs are involved in. About $40.4 \%$ of the small agricultural businesses were into large and small livestock farming, $28.5 \%$ of them practised crop farming, $18.5 \%$ were in agro-processing while those involved in both livestock and crop farming accounted for $11.9 \%$ of the total sample as indicated in Table 3 and Figure 6.

Perhaps, the popularity of livestock business can be attributed to the relatively low start-up capital required to start this business. Small-scale farmers often start with a few livestock that they rear on communal land free of charge before expanding their businesses and participating in large-scale cattle ranching. The farmers may erect simple, basic fencing and may not need large sheds as their herds are normally small (Harwell \& Pinkerton 2017).

\section{Form of business ownership}

Forms of business ownership were analysed to unravel the ownership patterns of SSABs. The results revealed that sole proprietorship is the most dominant form of ownership and accounted for $65.6 \%$ of the respondents' 


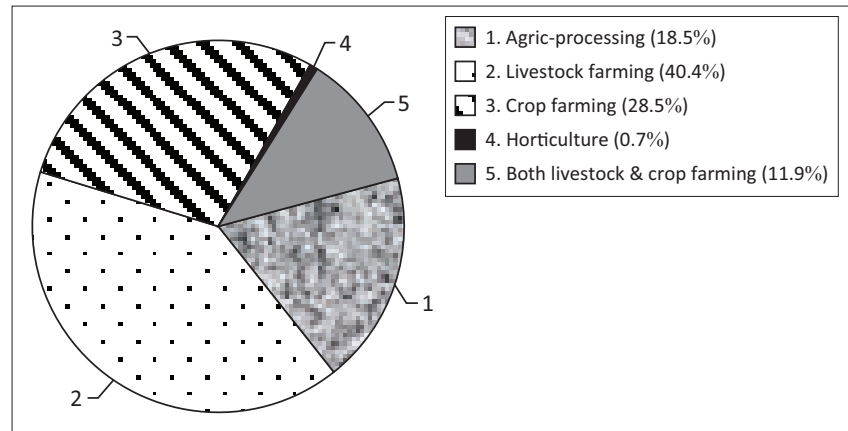

FIGURE 6: Types of business activities the SSABs practised.

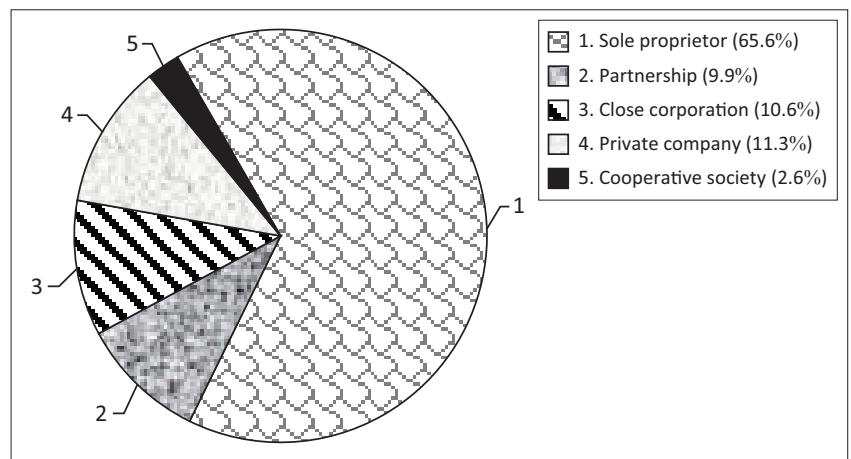

FIGURE 7: Form of business ownership.

business ownership. Perhaps SSABs' preference for this business structure is explained by the relative procedural ease with which sole proprietorships are created compared to larger business establishments. Figure 7 summarises the different forms of ownership of these SSABs.

\section{Number of employees in the business}

The study also explored the number of employees that SSABs employed. The results revealed that $48.3 \%$ of the SSABs employed between 1 and 5 people, $18.5 \%$ of the businesses had 6-20 employees, $14.6 \%$ employed 21-30 employees while $6.6 \%$ employed 31-40 employees. Consistent with the Small Business Act 102 of 1996 and Nieman's (2006) classifications of SMMEs, this finding suggests that the largest proportion of businesses fell under the micro-enterprises. Figure 8 illustrates the number of employees in the selected SSABs.

\section{Performance-related business issues}

The results of the study revealed that the majority of the SSABs studied were neither importing (92\%) nor exporting (62.9\%). Since involvement in export and import business is one of the components of the internationalisation of business, it can be argued that most SSABs lacked a strong drive towards internationalisation. However, when this limited internationalisation posture is conceived in conjunction with the financial performance of the business, a different picture emerged. For instance, $64.9 \%$ of SSABs' owners or managers reported that their pre-tax profit grew by between $1 \%$ and $20 \%$ in the previous five years, a phenomenon that is symptomatic of thriving business. In addition, about $42.3 \%$ of SSABs' owners or managers also

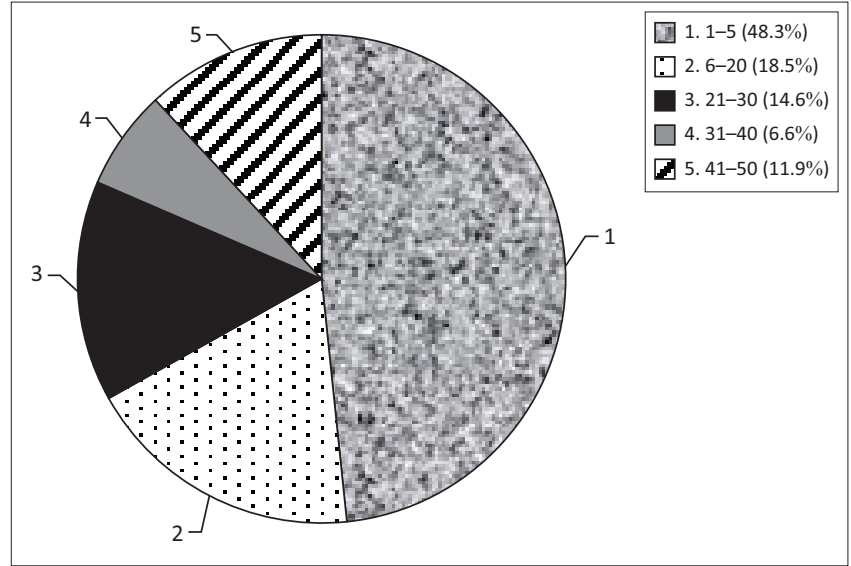

FIGURE 8: Number of employees in the business.

highlighted that their employment levels grew by between $1 \%$ and $20 \%$. Such evidence demonstrates that a sizable number of these businesses were on an encouraging growth path, judging from their employment performance.

\section{Engagement with foreign business}

SSABs' engagement with foreign businesses were analysed in order to understand the extent to which they were oriented towards globalisation. From the analysis, $45 \%$ of the SSABs surveyed had some foreign business involvement while 55\% did not have any foreign business dealings.

As indicated in Figure 9, 45\% of SSABs had some foreign engagements, $37.7 \%$ of them participated in foreign businesses, $37.1 \%$ participated in the exportation of products, while only $7.9 \%$ were involved in the importation of foreign technology. While SSABs' involvement in foreign engagements point to their potential to internationalise, their actual level of involvement across different activities is an emerging phenomenon. The low level of import and export orientation means that although SSABs are incrementally benefiting from globalisation, they have not fully harnessed the potentialities and benefits created by globalisation. This finding somewhat supports the claim that small businesses such as SSABs have not sufficiently benefited from internationalisation due to their weak international networks, their weak resources base and limited knowledge of world markets (Lloyd-Reason et al. 2009). Consistent with the transaction cost approach (TCA), itself the backbone of the NIE theory, the limited engagement of SSABs in international business (i.e. importing, exporting and foreign business ownership) may be a consequence of the high transaction costs arising from the complexities of locating dependable foreign partners and effectively exploiting global market information inherent in foreign networks.

\section{Foreign alliances}

The study also examined SSABs' extent of establishment of foreign alliances. The results in Figure 10 reveal that although a considerable proportion $(48.3 \%)$ of SSABs had no foreign alliances, the majority (51.7\%) had some foreign alliances. The results show that $18.5 \%$ of these agro-processing businesses 


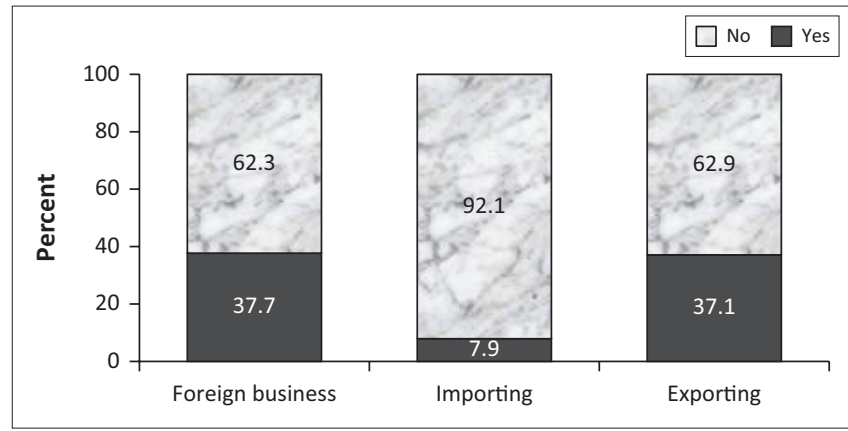

FIGURE 9: Engagement with foreign businesses.

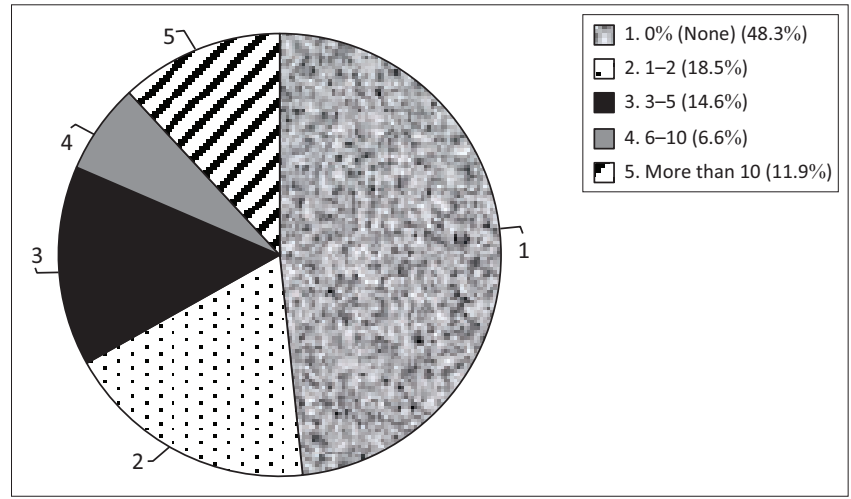

FIGURE 10: Extent to which businesses have established foreign alliances.

had 1-2 alliances, $14.6 \%$ had 3-5 alliances, $6.6 \%$ had $6-10$ alliances and $11.9 \%$ had more than 10 alliances. These figures also demonstrate that the majority (51.7\%) of the businesses had between 1 and 10 foreign alliances.

Based on this information, it can be concluded that although SSABs had foreign alliances, only a few of them had many alliances. It can be inferred that although SSABS are gradually realising the critical importance of globalisation through forging foreign alliances, few of them have fully exploited and subsequently benefited from these globalisation strategies. These aforementioned low levels of internationalisation are somewhat inconsistent with NIE thinking embedded in Perez-Aleman's (2012) argument that the increasing integration of small agricultural producers in the world markets can be attributed to: (1) the increasing production capabilities of such firms, which impact their capacity to survive and compete on a global scale, (2) knowledge flows that trigger the adaption of foreign practices, which leads to foreign innovation, and (3) strong institutions that facilitate knowledge flows that build local producers' capabilities to be conversant with global standards, conventions, rules, and shared expectations to ensure growth and competition in world markets. It can be inferred from the latter point that conversance with these global standards presupposes the prevalence of strong local regulatory and marketing institutions, which conduct research and advocacy work for SSABs. These institutions would also render SSABs with premium information on the technicalities of the world markets and their operating standards. While our evidence supported the prevalence of foreign alliances of varying scale, SSABs could not confirm the contribution of regulatory and marketing institutions.
The study results also addressed the question: Are there significant differences in SSABs' performance based on their extent of establishment of foreign alliances? If so, what is the nature of the difference?

Analysis of variance (ANOVA) was used to quantitatively ascertain the degree of relevance of the internationalisation indicator (i.e. foreign alliances) on the performance of smallscale agro-based businesses.

The results highlighted the number of employees including the owner or manager (a component of performance) to be significant $(F=15.999 ; p<0.05)$. This is an indication that the firm's orientation towards internationalisation (e.g. formation of foreign alliances, importing or exporting business) will contribute to a $16 \%$ increase in the number of employees they employ. Consistent with TCA, it is logical to assume that a firm will not engage in internationalisation if its return on labour is less than the marginal productivity of the labour. This interpretation seems to buttress the view that partnerships help SSABs and small farmers to scale their business operations and capture the opportunities (e.g. employment creation) created by the growing demand for agricultural products internationally (The Governing Council 2013). However, this finding is somewhat inconsistent with literature that claims that SMMEs' ability to internationalise, using foreign alliances, is often constrained by limited information on the location and analysis of markets, difficulties in contacting potential overseas partners, and complexities of obtaining reliable foreign representation (EU 2014).

The analysis of percentage growth in size or employment over the previous five years was found to be significant $(F=4.836 ; p<0.05)$. This may be an indication that firms which are engaged in internationalisation (e.g. those with foreign alliances, those importing or exporting) had a $4.8 \%$ increase in size or employment for the previous five years compared to firms that were not involved in internationalisation. This could be interpreted to mean that internationalisation potentially contributes to increases in SSABs' product competitiveness and profitability, which positively impact SSABs' capacity to expand the size of their workforce. The finding supports literature on the capacity of partnerships to generate employment through improvements in operational and economic efficiency among SSABs (FAO 2016). This contradicts the claim that small firms may be incapable of handling international partnerships due to lack of expertise, their management's lack of time investment due to their preoccupation with daily operations, and inability to integrate technology into their learning plans (Hyder 1998).

Analysis of variance was conducted on the SSABs' pre-tax profit for the previous five years to ascertain whether they are declining, growing or have remained stagnant. The analysis of percentage growth in pre-tax profit was found to be significant $(F=13.680 ; p<0.05)$. This is an indication that firms that are engaged internationalisation (e.g. those participating in foreign alliances, importing and exporting businesses) 
TABLE 3: Comparison of mean scores on the 'importance or relevance of internationalisation' index and business performance characteristics.

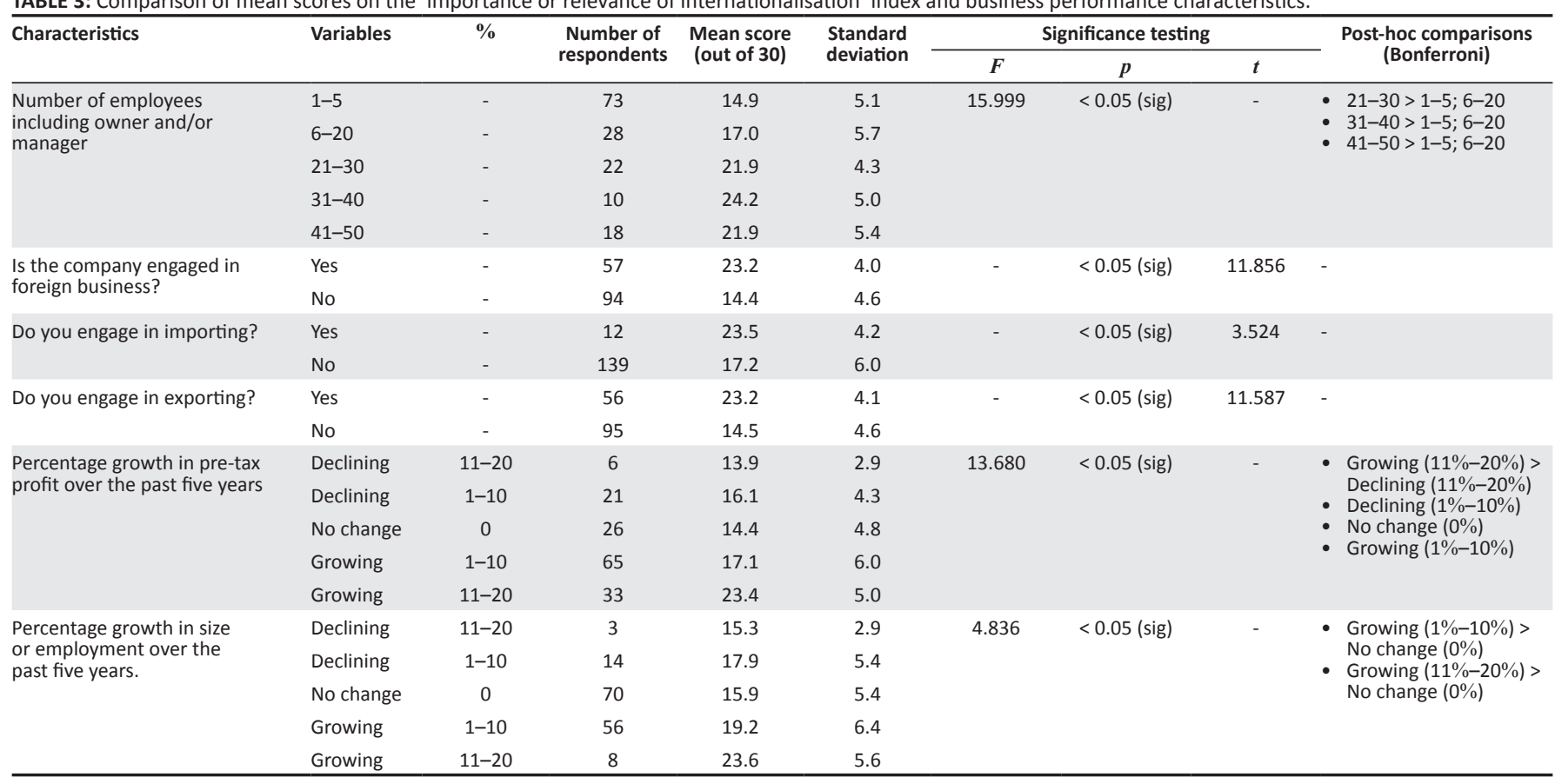

Sig, significance.

Note: Horticulture excluded because only one respondent selected this category.

realised a $13.7 \%$ increase in pre-tax profitability. The implication is that as firms engage in internationalisation, they might unlock their productive potential through sharing efficient methods of resource utilisation and effective methods of agricultural production, which contribute to an increase in their profitability. This growth in profits mirrors FAO's (2016) affirmation that the partnerships of small agricultural businesses tend to positively impact on net income through improved market access, increased productivity, improved product quality or reduced operational costs arising from the adoption of new technologies.

The results showed that the formation of foreign alliances significantly and positively related to the performance of SSABs in the Vryburg-Pokwani study areas at $p<0.05$ (significant). Furthermore, post-hoc comparisons (Bonferroni) results also showed that SSABs with 1-2 foreign alliances performed better than those with no foreign alliances, while SSABs with 6-10 foreign alliances performed better than those with no alliances, 1-2 and 3-5 foreign linkages respectively. This finding indicates that the more foreign alliances the SSABs created, the higher their performance. This finding buttresses the view that the international performance of small firms is bound to improve if they have potential overseas partners, contacts and customers that assist in identifying foreign business opportunities and locating or analysing markets and if the marketing barriers of these businesses are eliminated (OECD 2009). There is also evidence to support the view that foreign networks and lucrative supply chain links stimulate the performance of small firms (OECD 2009). The study demonstrates that there are positive and statistically significant differences in the performance of SSABs based on the extent to which they form foreign alliances. This finding supports the view that better access to international markets encourages farmers to invest in and increase the quantity, quality and diversity of goods they produce (International Fund for Agricultural Development [IFAD] Governing Council 2013) which are dimensions of business performance. There is also a reverse positive relationship as international partnerships help address the constraints smallholder farmers face in scaling up their businesses such as the high transaction costs of doing international business and lack of information on foreign markets (IFAD Governing Council 2013).

\section{Recommendations}

The comparatively lower participation of females in SSABs, compared to males, demonstrates the need to develop a gender-inclusive policy interventions in areas, such as the provision of financial, technical and managerial support to increase female involvement in such businesses. The mainstreaming of gender into agro-funding instruments and the provision of technical and managerial support systems would reduce the under-representation of women in agroprocessing ventures.

The dominance of SSABs male owners or managers above 40 years of age in agribusinesses suggests that farming is a fund-intensive activity, which is the predominant preserve of mature adults. The South African government's funding, training and technical support should target the youth (that is, those aged 18-35 years) to leverage youth's effective participation in SSABs and agribusinesses. Therefore, the Department of Trade and Industry (DTI) should develop a pro-youth farming strategy and incentivise these industries to increase youth participation in small-scale farming.

The emergent nature of foreign alliances of SSABs and their limited exploitation by these resource-constrained firms signal 
the need for new mechanisms for improving the value addition and innovation capabilities of SSABs to increase the attractiveness of their international collaborations and partnerships with foreign firms. Foreign partners are only keen to forge alliances with firms if they bring particular resource mobilisation, cost efficiency and efficient product or service generation capabilities and complementarities which are of the essence to the foreign partner. IDC (2015) highlights the fundamental importance of value chain development and innovation-oriented approaches that leverage economic linkages and enhance the competitiveness of firms.

An institutional perspective to improving the international networking capabilities of SSABs requires them to consider a holistic approach to improving their international foothold on world markets through inter alia aggressive marketing of their activities and products, mobilisation of resources collaboratively with the private sector, and investments in research and development that improve the innovative capabilities of such firms. Kawa and Kaitira (2007) recommend the establishment of an institutional framework that covers multiple areas of small agribusiness, namely:

- Improving the performance of the agricultural marketing systems based on needs assessments.

- Strengthening public-private partnership dialogue in the agribusiness development agenda and advocacy of their activities.

- Promoting investment in research and development in production, processing, storage, packaging, and handling technologies.

These interventions will contribute to the facilitation of linkages between local SSABs and international firms, and promote locally-processed agricultural products in international markets (Kawa \& Kaitira 2007).

\section{Implications for future research and conclusion}

The study findings suggest that although the majority $(51.7 \%)$ of SSABs had foreign alliances, a sizable percentage $(48.3 \%)$ of these businesses had no alliances at all. Future studies should establish whether those SSABs without such alliances are constrained financially from internationalising their businesses or do not perceive the benefits of internationalisation. Future studies should also examine the reasons for the limited internationalisation of rural SSABs including the critical success factors for internationalising SSABs.

Since SSABs with foreign alliances tended to outperform those that are dependent on their domestic links, future studies should examine the extent to which the economic benefits (e.g. knowledge of foreign markets, foreign expertise, transfer of foreign technologies) derived from internationalisation are reinvested into the businesses for their continued sustenance.

The study concludes that SSABs remain a predominantly mature adults (i.e. those above 40 years) and male dominated activity. Future studies need to unravel the role played by age, gender and type of businesses in the transition of SSABs from being small entities to becoming large, established businesses.

\section{Acknowledgements}

The authors wish to acknowledge the statistical analysis conducted by the statistician.

\section{Competing interests}

The authors declare that they have no financial or personal relationship that may have inappropriately influenced them in writing this article.

\section{Authors' contributions}

P.R. wrote all sections of this article. L.A. conducted the data collection process.

\section{References}

Agbobli, E., 2013, 'The influence of entrepreneurial and market orientations on smallscale rural agricultural enterprises in the Vryburg area', Unpublished PhD thesis, Central University of Technology, Free State.

Agbotame, L., 2015, 'The impact of selected aspects of globalisation on the performance of small-scale agro-based businesses in rural South Africa', Unpublished PhD thesis, Central University of Technology, Free State.

Allen, D.W. \& Lueck, D., 2002, 'The nature of the farm - Contracts, risk, and organization in agriculture, MIT Press, Cambridge, MA.

Berdegué, J., Biénabe, E. \& Peppelenbos, L., 2008, 'Innovative practice in connecting smallholder producers with dynamic markets', in B. Vorley, A. Fearne \& D. Ray (eds.), Regoverning markets: A place for small scale producers in modern agrifood chains? (p. 1-41), Gower Publishing, Aldershot.

Bititci, U.S., 1995, 'Modelling of performance measurement systems in manufacturing enterprises', International Journal of Production Economics 42, 137-147. https:// doi.org/10.1016/0925-5273(95)00172-7

Botha, R., 2015, Sub-Saharan Africa-Socio-political stability, economic performance and food security - A quantitative perspective, PricewaterhouseCoopers Inc, Cape Town.

Centre for Rural Legal Studies, 2003, Briefing paper: Agricultural trade, globalisation and farm workers, Eikestad Mall, Stellenbosch.

Chelliah, S., Pandian, S., Sulaiman, M. \& Munusamy, J., 2010, 'The moderating effect of firm size: Internationalisation of small and medium enterprises (SMEs) in the manufacturing sector', African Journal of Business Management 4(1), 3096-3109, viewed July 15, 2017, from https://www.researchgate.net/publication/228368315 The moderating_effect of firm size_Internationalization_of_small_and_medium enterprises SMEs in the manufacturing sector

Chiliya, N. \& Roberts-Lombard, M., 2012, 'Impact of level of education and experience on profitability of small grocery shops in South Africa', International Journal of Business Management and Economic Research 3(1), 462-470, viewed July 17, 2017 from http://www.ijbmer.com/docs/volumes/vol3issue1/ijbmer2012030110.pdf

Cooper, D.R. \& Schindler, P.S., 2011, Business research methods, 11th edn., McGraw Hill, Boston, MA

Department of Agriculture, Forestry and Fisheries, 2012, Trends in the agricultura sector, Government Printers, Pretoria.

Doyer, O., D'Haese, M., Kirsten, J. \& Van Rooyen, C., 2007, 'Strategic focus areas and emerging trade arrangements in the South African agricultural industry since the demise of the marketing boards', Agrekon 46(4), 494-513. https://doi.org/10.108 $0 / 03031853.2007 .9523783$

Dung, LV. \& Jenicek, V. 2008, 'Challenges with Vietnamese agricultural products joining WTO', Agricultura Tropica et Subtropica 41(2), 80-83, viewed July 30 2017, from https://www.agriculturaits.czu.cz/pdf_files/vol_41_2_pdf/lamvietdung jenicek.pdf

Dzansi, D., Rambe, P. \& Coleman, W., 2015, 'Enhancing new venture creation success in South Africa: A project management perspective', Problems and Perspectives in Management 13(2), 418-426, viewed August 3, 2017, from https:// businessperspectives.org/journals/problems-and-perspectives-in-management/ issue-2-spec-issue-2/enhancing-new-venture-creation-success-in-south-africa-aproject-management-perspective

Eisenhardt, K., 1989, 'Building theory from case study research', Academy of Management Review 14(4), 532-550. https://doi.org/10.5465/amr.1989.4308385

European Union (EU), 2014, Supporting the internationalisation of SMEs: How to support SME policy from structural funds, Guidebook Series, Belgium. 
Folan, P., Browne, J. \& Jagdev, H., 2007, 'Performance: Its meaning and content for today's business research' Computers in Industry 58, 605-620. https://doi.org/ today's business research', Comput
10.1016/j.compind.2007.05.002

Food and Agriculture Organization of the United Nations (FAO), 1997, Agro-processing industry and their challenges, FAO, Rome.

FAO, 2016, Public-private partnerships for agribusiness development - A review of international experiences, FAO, Rome.

Fouché, C. \& De Vos, A., 2011, 'Formal formulations', in A. De Vos, H. Strydom, C. Fouché \& C. Delport (eds.), Research at grassroots: For the social sciences and human service professions, pp. 89-130, Van Schaik Publishers, Pretoria.

Frimpong, S.M., 2015, 'Agribusiness insights from Ghana', in PricewaterhouseCoopers, Africa - Are you in for the ride'? Agribusinesses insights survey 2014/2015. Key trends, challenges \& future prospects/March 2015, p. 4, viewed 27 May 2017 from https://www.pwc.co.za/en/assets/pdf/agribusinesses-insights-survey-20142015.pdf

Gandhi, V.P., 2014, 'Growth and transformation of the agribusiness sector: Drivers, models and challenges', Indian Journal of Agricultural Economics 69(1), 44-74.

Gomes, R., 2006, 'Upgrading without exclusion: Lessons from SMEs in fresh fruit producing clusters in Brazil', in C. Pietrobelli \& R. Rabellotti (eds.), Upgrading to compete: Global value chains, clusters, and SMEs in Latin America, Inter-American compete: Global value chains, clusters, and SMEs in Latin America, Inter-American University, Washington, DC.

Gulati, R., 1998, 'Alliances and networks', Strategic Management Journal 19, 293-317. https://doi.org/10.1002/(SICI)1097-0266(199804)19:4\%3C293::AID-SMJ982\% 3E3.0.CO;2-M

Ha, T., Bosch, O. \& Nguyen, M., 2015, 'Necessary and sufficient conditions for agribusiness success of small-scale farming systems in northern Vietnam', Busines and Management Studies 1(2), 36-44. https://doi.org/10.11114/bms.v1i2.820

Harwell, L. \& Pinkerton, F., 2017, Housing, fencing, working facilities \& predators, GoatWold.com, viewed 06 April 2016, from http://www.goatworld.com/articles/ fencing/fencing1.shtml

Hyder, A.S., 1998, Strategic alliances by small-and medium-sized firms: An explorative study and a conceptual framework, University College of Gavle-Sandviken, Gavle, Sweden.

Industrial Development Corporation (IDC), 2015, Integrated report for the year ended 31 March 2015: Advancing industrial development, Industrial Development Corporation of South Africa Limited, Cape Town.

International Fund for Agricultural Development (IFAD), Governing Council, 2013, The power of partnerships: Forging alliances for sustainable small holder agriculture, Rome, viewed 06 April 2017, from https://www.ifad.org/documents/10180/ a2f40177-b333-47ec-ae44-6e3de90968e1

Jabbar, M.A. \& Akter, S., 2008, 'Market and other factors affecting farm specific production efficiency in pig production in Vietnam', Journal of International Food \& Agribusiness Marketing 20(3), 29-53. https://doi.org/10.1080/08974430802157606

Kawa, I.H. \& Kaitira, L.M., 2007, Enhancing smallholder farmers' market competitiveness in Tanzania: Case study \#6-7 of the program-food policy for developing countries: in Tanzania: Case study \#6-7 of the program-food policy for developing countries:
The role of government in the global food system, Cornell University, Ithaca, NY.

Kishna, M., Niesten, E., Negro, S. \& Hekkert, M., 2015, 'The role of strategic alliances in creating technology legitimacy: A study on the emerging field of bio-plastics', Innovation Studies Utrecht (ISU) Working Paper \#15.03, ISU, Utrecht.

Kaplan, R.S. \& Norton, D.P., 1992 (January/February), 'The balanced scorecardmeasures that drive performance', Harvard Business Review, 71-79.

Kirsten, J. \& Sartorius, K., 2002, 'Linking agribusiness and small-scale farmers in developing countries: Is there a new role for contract farming?', University of Pretoria working paper 2002-13, Department of Agricultural Economics, Extension and Rural Development, Pretoria.

Krueger, L. \& Neuman, W., 2006, Social work research methods. Qualitative and quantitative applications, Pearson Education, Boston, MA

Leedy, P.D. \& Ormrod, J.E., 2010, Practical research planning and design, 9th edn., Pearson Education, Hoboken, $\mathrm{NJ}$.

Lin, H., 2012, 'Strategic alliances for environmental improvements', Business and Society 51(2), 335-348, viewed June 13, 2017, from http://journals.sagepub.com/ doi/pdf/10.1177/0007650312437918

Louw, A., 2007, 'Agribusiness issues', working paper for ABSA Agribusiness Chair, Department of Agricultural Economics and Rural Development, University of Pretoria, Pretoria.

Louw, A. \& Emongor, R.A., 2004, Securing small producer participation in restructured national and regional agri-food systems, International Institute for Environment and Development (IIED), London.

Louw, A., Nhemachena, C. \& Van Zyl, S., 2008, 'Regoverning markets: Agribusiness linkages in the southern African region: Small farmer participation', Policy Brief 2, Department of Agricultural Economics, Extension and Rural Development, University of Pretoria, Pretoria.

Louw, A., Geyser, M., Troskie, G., Van der Merwe, M., Scheltema, N \& Nicholson, R. 2010, Determining the factors that limit agro-processing development in the maize milling industry in rural areas in South Africa, Department of Agricultura Economics, Extension, and Rural Development, Faculty of Natural and Agricultura Sciences, University of Pretoria, Pretoria.

Lloyd-Reason, L., Deprey, B. \& Ibeh, K., 2009, Top barriers and drivers to SME internationalisation, report by the OECD Working Party on SMEs and Entrepreneurship, OECD, Paris.

Matthews, R.C.O., 1986, 'The economics of institutions and the sources of economic growth', The Economic Journal 96, 903-918, viewed June 13, 2017, from https:// www.jstor.org/stable/2233164?seq=1\#page_scan_tab_contents
McDermott, G., Corredoira R. \& Kruse G., 2009, 'Public-private institutions as catalysts of upgrading in emerging market societies', Academy of Management Journal 52 1270-1296, viewed June 14, 2017, from https://www.jstor.org/stable/40390369? seq=1\#page_scan_tab_contents

Media Club South Africa, 2018, South Africa's economy: Key sectors, viewed Novembe 15, 2017, from http://mediaclub.co.za/economy/37-economy/economy-bg/111sa-economy-key-sectors\#ixzz59hwd9gMy

Mellen, S., 2009, 'New insights on the internationalisation process of SMEs: A study of foreign market knowledge development', published doctoral dissertation, Stockholm School of Economics, Stockholm.

Memedovic, O. \& Shepherd, A., 2009, Agri-food value chains and poverty reduction: Overview of main issues, trends and experiences, Working Paper 12/2008, United Nations Industrial Development Organisation, Vienna.

Milgrom, P. \& Roberts, J., 1992, Economics, organisation and management, PrenticeHall International, Englewood Cliffs, NJ.

Madhoushi, M., Sadati, A., Delavari, H., Mehdivand, M. \& Mihandost, R. 2011 'Entrepreneurial orientation and innovation performance: The mediating role of knowledge management', Asian Journal of Business Management 3(4), 310-316.

Mpiti, N., 2016, 'Influence of financial resources on performance of SMMEs in Free State: A case of afro hair salons in Mangaung Metropolitan Municipality', master's thesis, Central University of Technology, Free State.

Mucavele, F., 2009, 'True contribution of agriculture to economic growth and poverty reduction: Malawi, Mozambique and Zambia synthesis report', 9th Annual Food Agriculture and Natural Resources Policy Analysis Network (FANRPAN) Policy Dialogue, Maputo, August-September 2009.

Ndjike, T., 2016, 'Emerging technologies to enhance the networking capabilities, export orientation and absorptive capacity of manufacturing SMMEs in the South Africa (Free State): An internationalisation perspective', proposal submitted to Faculty of Management Sciences, Central University of Technology, Bloemfontein.

Nieman, G., 2006, Small business management. A South African approach, Van Schaik Publishers, Pretoria.

Organisation for Economic Cooperation and Development (OECD), 2009, Top barriers and drivers to SME internationalisation, Report by the OECD Working Party on SMEs and Entrepreneurship, OECD, Paris.

Olomola, A., 2013, Policy options for agricultural investments and governance of markets: In support of small-scale agriculture in Nigeria, Research report, markets: In support of small-scale agriculture in Nigeria, Resea
International Food Policy Research Institute (IFPRI), Washington, DC.

Perez-Aleman, P., 2012, 'Global standards and local knowledge building: Upgrading small producers in developing countries', PNAS 109(31), 12344-12349, viewed September 17, 2017, from http://www.pnas.org/content/109/31/12344. viewed S

Platteau, J.P., 2008, 'The causes of institutional inefficiency: A development perspective', in E. Brousseau \& J. Glachant (eds.), New institutional economics: A guidebook, pp. 443-542, Cambridge University Press, Cambridge.

PricewaterhouseCoopers (PWC), 2015, Agribusinesses insights survey 2014/2015 Agribusiness in Africa - CEO insights, PWC, Cape Town.

Rambe, P. \& Mokgosi, B., 2016, 'The influence of personal, family and social variables on technology-oriented venture creation: Theoretical case of internet cafés in Bloemfontein, South Africa', The Journal of Applied Business Research 34(4) 1063-1078, viewed June 13, 2017, from https://www.cluteinstitute.com/ojs/ index.php/JABR/article/view/9722

Reardon, T. \& Barrett, C.B., 2000, 'Agro-industrialisation, globalisation, and international development: An overview of issues, patterns, and determinants', Agricultura Economics 23, 195-205, viewed June 5, 2017, from http://ageconsearch.tind.io/ record/176200/files/agec2000v023i003a001.pdf

Republic of South Africa, 2003, South Africa's Small National Business Act, Government Gazette 461, Cape Town, 26 November 2003.

Rothaermel, F. \& Boeker, W., 2008, 'Old technology meets new technology: Complementarities, similarities, and alliance formation', Strategic Management Journal 29, 47-77, viewed October 5, 2017, from https://www.scheller.gatech. edu/directory/faculty/rothaermel/pubs/08SMJ.pdf

Shah, R.H. \& Swaminathan, V., 2008, 'Factors influencing partner selection in strategic alliances: The moderating role of alliance context', Strategic Management Journal 29(5), 471-494, viewed October 4, 2017, from http://onlinelibrary.wiley.com/doi/ 10.1002/smj.656/abstract

Van Tulder, R., Seitanidi, M., Crane, A. \& Brammer, S., 2015, 'Enhancing the impact of cross-sector partnerships - Four impact loops for channelling partnership studies', Journal of Business Ethics, viewed October 15, 2017, from https://link.springer com/article/10.1007/s10551-015-2756-4

Weilbach, F., 2015, 'Introduction to the publication: A word from Frans Weilbach - PwC South Africa Agribusiness Industry Leader', in PricewaterhouseCoopers (ed.), AfricaAre you in for the ride? Agribusinesses insights survey 2014/2015. Key trends, challenges \& future prospects/March 2015, viewed 06 April 2017, from https:// www.pwc.co.za/en/assets/pdf/agribusinesses-insights-survey-2014-2015.pdf

Wiklund, J. \& Shepherd, D., 2005, 'Entrepreneurial orientation and small business FP: A configuration approach', Journal of Business Venturing 20, 71-91. https://doi. org/10.1016/j.jbusvent.2004.01.001

Wroblewski, J. \& Wolff, H., 2010, Risks to agribusiness investment in sub-Saharan Africa, Prepared for the agricultural policy and statistics team Bill \& Melinda Gates Foundation, Evans School Policy Analysis and Research Group, University of Washington, Seattle.

Zikmund, W.G., Babin, B.J., Carr, J.C. \& Griffin, M., 2013, Business research methods, 9th edn., Cengage Learning, Toronto. 